\title{
Diabetes mellitus accelerates fatty degeneration of the supraspinatus muscle after tendon tear: An experimental study in rats
}

\author{
Diabetes mellitus tendon yırtığı sonrasında supraspinatus kasının \\ yağlı dejenerasyonunu hızlandırır: Sıçanlarda deneysel çalışma
}

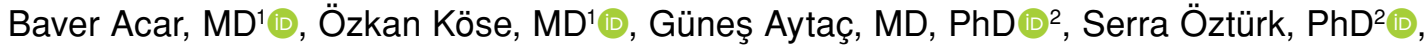 \\ Asiye Kübra Göksu, $\mathrm{PhD}^{3}{ }^{(D)}$, Gamze Tanrıover, $\mathrm{PhD}^{3}\left(\mathbb{D}\right.$, Muzaffer Sindel, $\mathrm{PhD}^{2}$ (D)
}

'Department of Orthopedics and Traumatology, University of Health Sciences, Antalya Training and Research Hospital, Antalya, Turkey

${ }^{2}$ Department of Anatomy, Akdeniz University Faculty of Medicine, Antalya, Turkey

${ }^{3}$ Department of Histology and Embryology, Akdeniz University Faculty of Medicine, Antalya, Turkey

\begin{abstract}
Objectives: This study aims to evaluate the effect of diabetes mellitus (DM) on intramuscular fatty degeneration after a fullthickness supraspinatus (SS) tendon tear in rats.

Materials and methods: The study included 24 adult male Wistar Albino rats (age, 18 to 24 weeks; weighing, 320-380 g) randomized into a sham group $(n=6)$, control group $(n=6)$ and experimental group ( $\mathrm{n}=12$ ). Rats with fasting blood glucose levels $\geq 250 \mathrm{mg} / \mathrm{dL}$ at each measurement after an injection of streptozotocin were accepted to have DM. On the seventh day of the study, the SS muscles of the rats in the experimental and control groups were cut from the insertion. All animals were performed euthanasia four weeks after the surgical procedure and SS muscles were excised completely. Fatty degeneration in the SS muscle was assessed histologically and immunohistochemically with oil red $\mathrm{O}$ and peroxisome proliferatoractivated receptor gamma (PPAR- $\gamma$ ) staining using histological score (H-score) and quantitative methods.
\end{abstract}

Results: More intense oil red O and PPAR- $\gamma$ staining was observed in all regions of the SS muscles of the experimental group compared to control and sham groups $(\mathrm{p}<0.05)$.

Conclusion: The results of this study showed that DM accelerates intramuscular fatty degeneration after SS tendon tears. Fatty degeneration should be monitored closely in diabetic patients with rotator cuff tear who were selected for conservative treatment and early surgical treatment should be considered as an option.

Keywords: Diabetes mellitus; fatty degeneration; oil red O; peroxisome proliferator-activated receptor gamma; rotator cuff tear; supraspinatus muscle.

\section{ÖZ}

Amaç: Bu çalışmada, sıçanlarda tam kalınlıkta supraspinatus (SS) tendon yırtığı sonrasında diabetes mellitus (DM)'un intramusküler yağlı dejenerasyon üzerindeki etkisi değerlendirildi.

Gereç ve yöntemler: Çalışmaya taklit grubuna $(n=6)$, kontrol grubuna $(n=6)$ ve deney grubuna $(n=12)$ randomize edilmiş 24 erişkin erkek Wistar Albino sıçanı (yaş, 18-24 hafta; ağırlık, 320-380 g) dahil edildi. Streptozotosin enjeksiyonu sonrası her ölçümde açlık kan glikoz seviyeleri $\geq 250 \mathrm{mg} / \mathrm{dL}$ olan sıçanlar DM'li kabul edildi. Çalışmanın yedinci gününde, deney ve kontrol gruplarındaki sıçanların SS kasları tam kat kesildi. Tüm hayvanlara cerrahi işlemden dört hafta sonra ötanazi uygulandı ve SS kasları tamamen çıkarıldı. Supraspinatus kasındaki yağlı dejenerasyon histolojik ve immünhistokimyasal olarak oil red O ve peroksizom proliferatör aktive edici reseptör gamma (PPAR- $\gamma$ ) boyaması ile histolojik skoru (H-skor) ve kantitatif yöntemler kullanılarak değerlendirildi.

Bulgular: Deney grubunun SS kaslarının tüm bölgelerinde kontrol ve taklit gruplarına göre daha yoğun oil red O ve PPAR- $\gamma$ boyaması gözlemlendi $(\mathrm{p}<0.05)$.

Sonuç: Bu çalışmanın sonuçları, DM'nin SS tendon yırtığı sonrası intramusküler yağ dejenerasyonunu hızlandırdığını gösterdi. Konservatif tedavi için seçilen rotator manşet yırtığı olan diyabetik hastalarda yağlı dejenerasyon yakından izlenmelidir ve erken cerrahi tedavi bir seçenek olarak düşünülmelidir.

Anahtar sözcükler: Diabetes mellitus; yağlı dejenerasyon; oil red O; peroksizom proliferatör aktive edici reseptör gamma; rotator manşet yırtı̆̆1; supraspinatus kası.

Received: August 10, 2018 Accepted: October 03, 2018

Correspondence: Baver Acar, MD. SBÜ Antalya Eğitim ve Araştırma Hastanesi Ortopedi ve Travmatoloji Kliniği, 07100 Muratpaşa, Antalya, Turkey. Tel: +90 5324628423 e-mail: baveracar@hotmail.com 
Rotator cuff (RC) tear is one of the most common shoulder disorders that cause pain and disability. ${ }^{[1,2]}$ Despite its high prevalence, currently there is no established treatment algorithm for RC tears. Nevertheless, the most widely accepted management strategy is to separate these patients into three distinct clinical groups based on the potential risks and proposed benefits of either surgical intervention or conservative treatment. In general, surgical repair is recommended in acute traumatic RC tears (i) at an early stage. In massive retracted degenerative $\mathrm{RC}$ tears (ii), conservative treatment should be preferred to surgical repair whenever possible. Finally, nonacute degenerative RC tears (iii) should initially be treated with conservative treatment, and surgical repair should be performed in patients in whom conservative treatment fails. ${ }^{[1]}$ However, in the final group, discussions continue regarding which treatment is more beneficial and successful. There are contradictory findings in the relevant literature. Some authors have suggested that there is no difference between conservative treatment and surgical treatment groups, while others claim that surgical treatment is superior. ${ }^{[1-6]}$

There are many factors that may affect the success of surgical treatment, such as the age of the patient, the size of the tear, the amount of degeneration in the tendon, the degree of fatty degeneration in the muscle and the type of surgical technique. It is well-known that fatty degeneration begins following a complete tendon rupture and it has been previously shown in several studies that fatty degeneration is irreversible. ${ }^{[7,8]}$ It has also been shown that as the amount of fatty degeneration increases, the clinical outcome worsens. Melis et al. ${ }^{[8]}$ demonstrated that moderate supraspinatus (SS) fatty infiltration appeared averagely three years after the onset of symptoms and severe fatty infiltration averagely five years after the onset of symptoms. Melis et $a .^{[8]}$ recommended that in tears involving more than one tendon, surgical treatment should be applied before stage- 2 fatty degeneration and atrophy (positive tangent sign) occur. However, it is not known which risk factors accelerate the formation of fatty degeneration after RC tears.

Diabetes mellitus (DM) has adverse effects on all organ systems including the musculoskeletal system $^{[10,11]}$ and we hypothesized that DM might accelerate fatty degeneration. To our knowledge, no study has been conducted on the natural history of RC tears in patients with DM. Understanding the natural history of fatty degeneration in DM will help surgeons to select the proper treatment for RC tear patients with DM. The question of whether fatty degeneration progresses rapidly after $\mathrm{RC}$ tears in diabetic patients remains unanswered. As fatty degeneration affects the outcome of the surgical operation, the answer to this question will be valuable for the timing of surgical management in diabetic patients. Therefore, in this study, we aimed to evaluate the effect of DM on intramuscular fatty degeneration after a fullthickness SS tendon tear in rats.

\section{MATERIALS AND METHODS}

This study was conducted at Akdeniz University, Medical Faculty, Experimental Animals Research Center between April 2016 to October 2016. The study included 24 adult male Wistar Albino rats (age, 18 to 24 weeks; weighing 320-380 grams). The animals were fed a standard laboratory diet and water, and were housed in standard cages in an airconditioned room with a 12-hour light-dark cycle, and constant temperature $\left(20-22^{\circ} \mathrm{C}\right)$ and relative humidity (65-70\%). All experimental protocols were approved by the Akdeniz University Ethics Committee for Experimental Animal Research (Institutional Review Board Approval: B.30.2.AKD.0.05.07.00/19). The study was carried out in the "Experimental and Research Laboratories" at the same institution. Before initiation of the study, to ensure that all enrolled rats were euglycemic (blood glucose level $<120 \mathrm{mg} / \mathrm{dL}$ ), the 12-hour fasting blood glucose

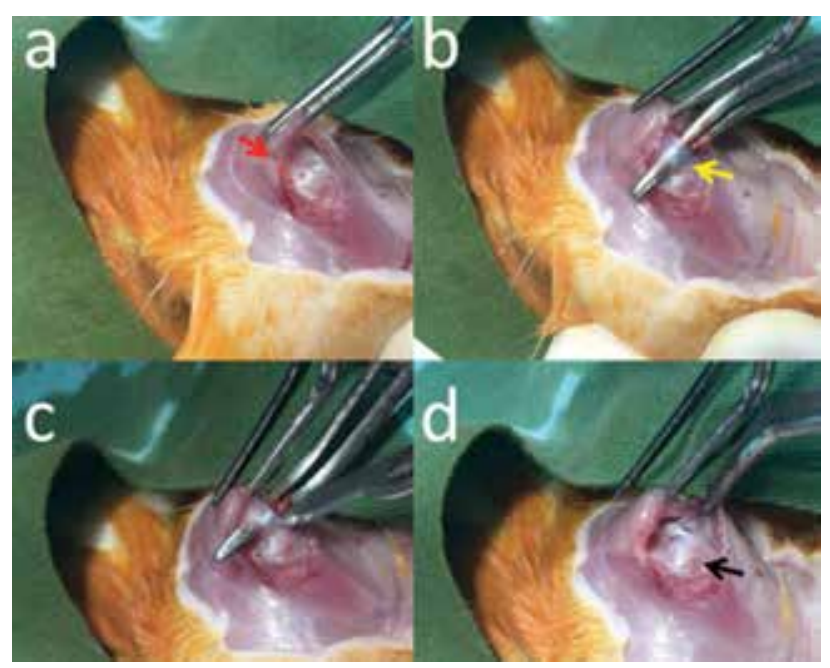

Figure 1. Surgical procedure for rotator cuff tear. (a) Deltoid muscle (red arrow) was detached from acromial edge and rotator cuff was exposed. (b) Supraspinatus muscle and its insertion on greater tuberosity of proximal humerus was identified (yellow arrow). (c) Supraspinatus tendon was sharply detached from insertion on greater tuberosity. (d) Stump of tendons was retracted inward by contraction of rotator cuff muscles and humeral head (black arrow) was exposed. 
level was measured and was determined to be $101.1 \pm 8.8 \mathrm{mg} / \mathrm{dL}$ (range, $89-120 \mathrm{mg} / \mathrm{dL}$ ). The rats were randomly separated into three groups as the sham group $(n=6)$, control group $(n=6)$ and experimental group $(n=12)$.

The rats were anesthetized with isoflurane and diabetes was induced with an intraperitoneal injection of streptozotocin (STZ). The STZ (Sigma-Aldrich, St. Louis, MO, USA; Cat. \# S0130) was dissolved in citrate buffer $(0.1 \mathrm{M}, \mathrm{pH} 4.5)$ solution. Following the STZ injection, the 12-hour fasting blood glucose levels were measured on the first, second and fourth days. Rats with fasting blood glucose levels $\geq 250 \mathrm{mg} / \mathrm{dL}$ at each measurement were accepted to have DM. ${ }^{[12]}$

The control and sham group animals received an intraperitoneal injection of citrate buffer solution only. Similarly, the 12-hour fasting blood glucose levels were measured on the first, second and fourth days in these animals and a euglycemic state was ensured. Throughout the whole study period, the blood glucose levels were measured every three days in all rats to ensure maintenance of a euglycemic and hyperglycemic state in the control and diabetic rats, respectively.

A RC tear (tendon detachment) model was created in the rats in accordance with previous studies. ${ }^{[13]}$ All operations were performed using a sterile technique with the rat in the lateral decubitus position on the seventh day of the study. Preoperatively, $15 \mathrm{mg} / \mathrm{kg}$ cefazolin sodium was administered intramuscularly for infection prophylaxis. The rats were anesthetized with a $5 \mathrm{mg} / \mathrm{kg}$ xylazine hydrochloride $(\mathrm{HCl})$ and $35 \mathrm{mg} / \mathrm{kg}$ ketamine $\mathrm{HCl}$ combination. In the sham group, only a skin incision was performed and then

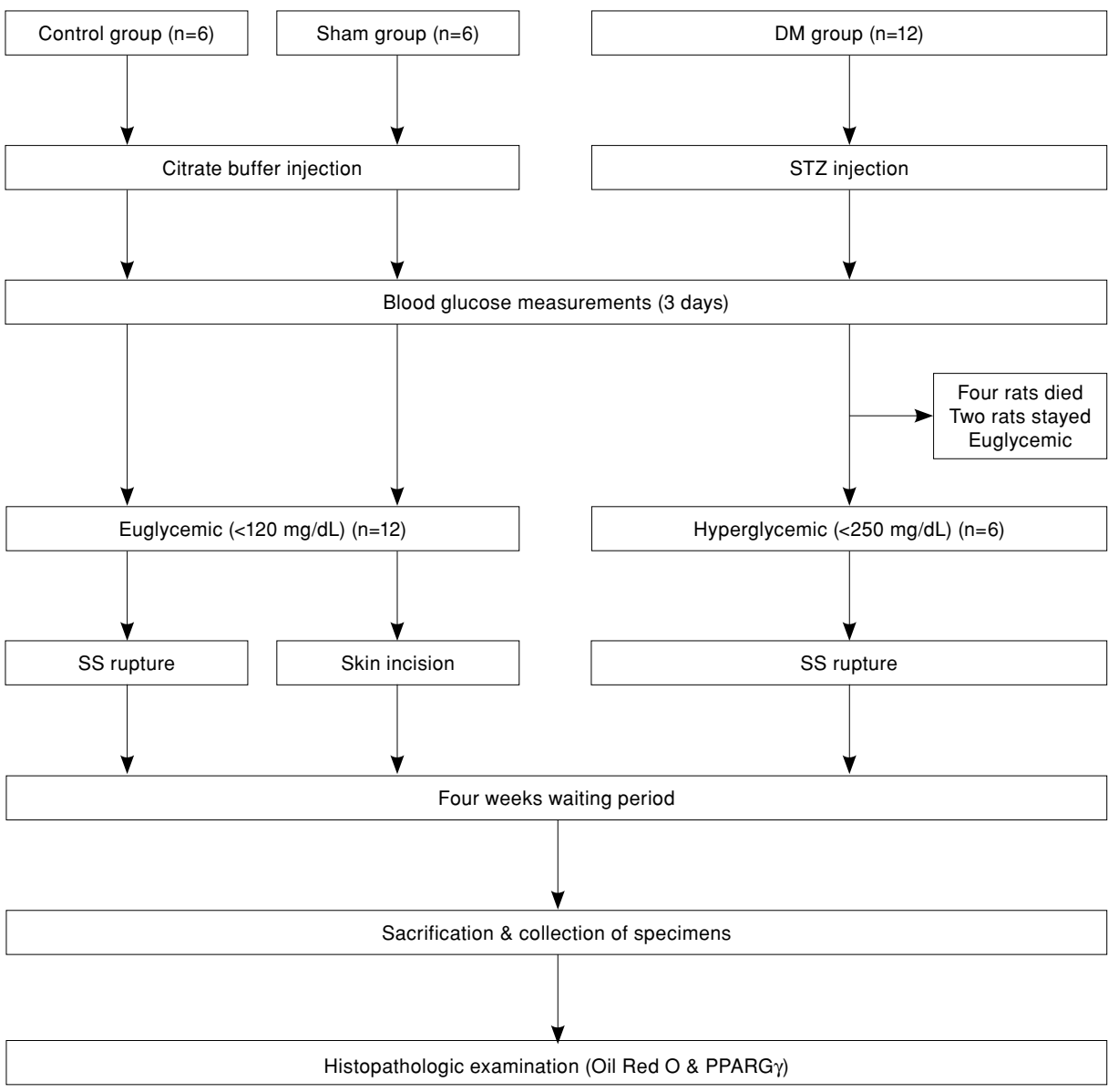

Figure 2. Schematic representation of experimental flow. DM: Diabetes mellitus; STZ: Streptozotocin; SS: Supraspinatus; PPAR $\gamma$ : Peroxisome proliferator-activated receptor gamma. 
closed with a 3-0 non-absorbable polyester suture. In the experimental and control groups, the deltoid was detached from the acromial edge and the RC was exposed (Figure 1a). The SS muscle and its insertion on the greater tuberosity of the proximal humerus were identified (Figure 1b). The SS tendon was sharply detached from the insertion on the greater tuberosity using a scalpel blade (Figure 1c). The stump of the tendons was retracted inward by the contraction of the $\mathrm{RC}$ muscles so that a defect was created (Figure 1d).

After the induction of DM in the experimental group, blood glucose levels stayed lower than $250 \mathrm{mg} / \mathrm{dL}$ in two rats and these were excluded from the study, while four rats died after the surgical procedure. Thus, the study was completed with the remaining six rats in the diabetic group. A schematic representation of the experimental flow is shown in Figure 2.

The animals were euthanized four weeks after the surgical procedure. Euthanasia was applied with an intramuscular injection of high dose ketamine $\mathrm{HCl}$ and xylazine $\mathrm{HCl}$. The right scapulae of the rats were removed surgically and the SS muscles were harvested. Each SS muscle was divided into three equal zones (distal, middle and proximal portions). Each zone was further divided into two sections for histological and immunohistochemical assessments: oil red $\mathrm{O}$ and peroxisome proliferator-

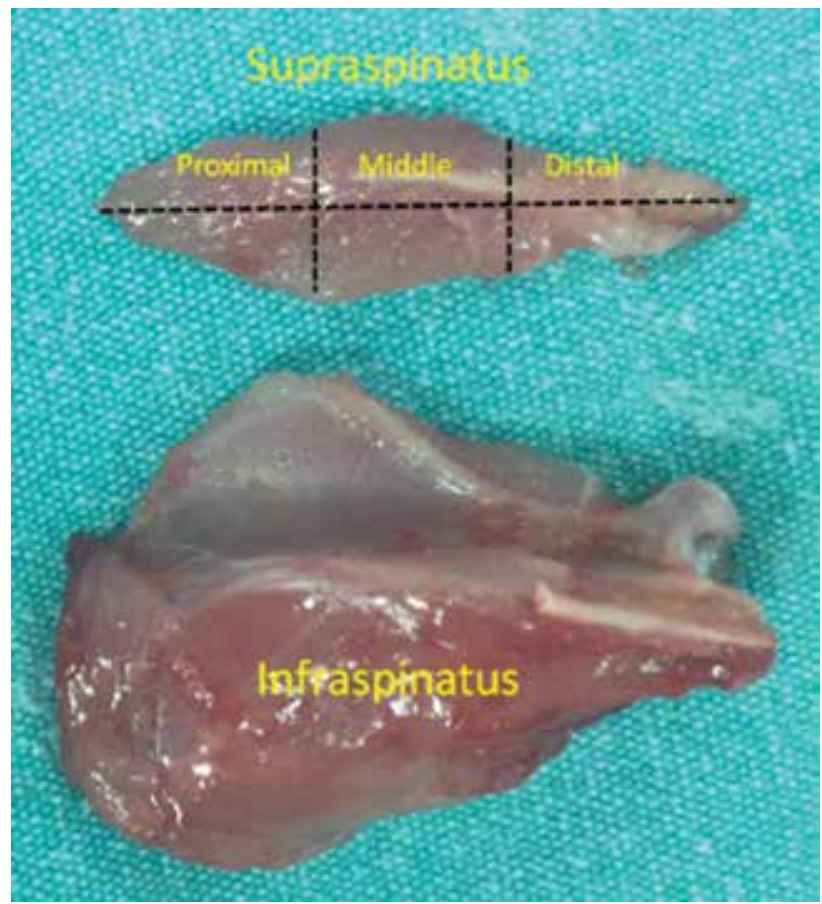

Figure 3. Surgically removed scapula, supraspinatus and infraspinatus muscles. Supraspinatus muscle was divided into three zones as distal, middle and proximal. activated receptor gamma (PPAR- $\gamma$ ) (Figure 3). Half of the muscle sections were paraffin processed for histological sections, and the other half were freshfrozen for immunohistochemical analysis.

The SS muscles were embedded in an optimal cutting temperature compound (Leica Microsystems, Nussloch, Germany) and were rapidly frozen in liquid nitrogen. Frozen sections ( $5 \mu \mathrm{m}$ thick) were taken from the proximal, central and distal portions of the SS muscle and stained with oil red O solution (Sigma-Aldrich, Darmstadt, Germany) and counterstained with hematoxylin (Sigma-Aldrich, Darmstadt, Germany). The specimens were evaluated under light microscopy (Zeiss-Axioplan, Oberkochen, Germany) for staining intensity. Each specimen was scanned at $\times 40$ magnification, digitized and then six different areas were analyzed using histological-score (H-score). The mean $\mathrm{H}$-score in the six areas was determined as the H-score for that specimen.

Peroxisome proliferator-activated receptor gamma is a nuclear receptor that regulates fatty acid storage and glucose metabolism through stimulation of lipid uptake and adipogenesis by fat cells. It also mediates adipocyte differentiation from pre-adipocyte precursor cells into adipocytes that are capable of lipid storage particularly in muscle tissue. Therefore, identification and quantification of this receptor within the muscle tissue provide direct information on the fat metabolism and fatty degeneration. ${ }^{[14]}$

Peroxisome proliferator-activated receptor gamma receptor was determined using immunohistochemistry. All histopathological scoring and staining intensity procedures were performed by two independent observers who were blinded to the study groups. The mean $\mathrm{H}$-score of the two observers was used for the final statistical analysis. The ratio of the number of stained nuclei to the total number of nuclei was calculated to determine the staining percentage.

\section{Statistical analysis}

The data were presented as mean \pm standard deviation. Comparisons between multipleindependent groups were performed with Kruskal-Wallis variance analysis and comparisons between two independent groups were performed using the Mann-Whitney $\mathrm{U}$ test. Statistical significance was set at $\mathrm{p}<0.05$.

\section{RESULTS}

In the hyperglycemic group, all regions of the SS muscle were more densely stained with PPAR- $\gamma$ than 
TABLE I

Summary of peroxisome proliferator-activated receptor gamma immunohistochemistry staining

\begin{tabular}{|c|c|c|c|c|c|}
\hline \multirow{2}{*}{ PPAR $\gamma$} & Sham group & Control group & DM group & & \\
\hline & Mean $\pm S D$ & Mean \pm SD & Mean \pm SD & Significance & $p$ value \\
\hline Proximal & $18.2 \pm 5.6$ & $19.5 \pm 14.3$ & $32.0 \pm 13.5$ & 0.003 & $0.786^{*}$ \\
\hline Central & $14.5 \pm 8.8$ & $20.3 \pm 10.4$ & $38.2 \pm 9.9$ & 0.001 & $0.202^{*}$ \\
\hline Distal & $5.9 \pm 3.4$ & $7.5 \pm 5.7$ & $26.3 \pm 11.4$ & 0.001 & $0.476^{*}$ \\
\hline
\end{tabular}

PPAR $\gamma$ : Peroxisome proliferator-activated receptor gamma; DM: Diabetes mellitus; SD: Standard deviation; Second column $\left(^{\star}\right)$ p values shows the comparison of Sham and Control groups.

in the control and sham groups (Figure 4). There was no statistically significant difference between the control and sham groups (Table I).

In the hyperglycemic group, oil red $\mathrm{O}$ was observed to be denser in all regions of the SS muscle than in the control and sham groups (Figure 5). There was no statistically significant difference between the control and sham groups (Table II).

\section{DISCUSSION}

This study was designed to evaluate the effect of DM on intramuscular fatty degeneration after a full-thickness SS tendon tear in rats. In this in vivo experiment, the histological and immunohistochemical analyses clearly demonstrated that fatty degeneration was more pronounced in the experimental diabetes group. These results indicated that DM plays an important role in the progression of fatty degeneration following $\mathrm{RC}$ tear.

Therefore, it was speculated that the timing of surgery may be important in RC repairs of diabetic patients with poor glycemic control. Since fatty degeneration progresses rapidly in diabetic patients, early surgical treatment may be more appropriate for

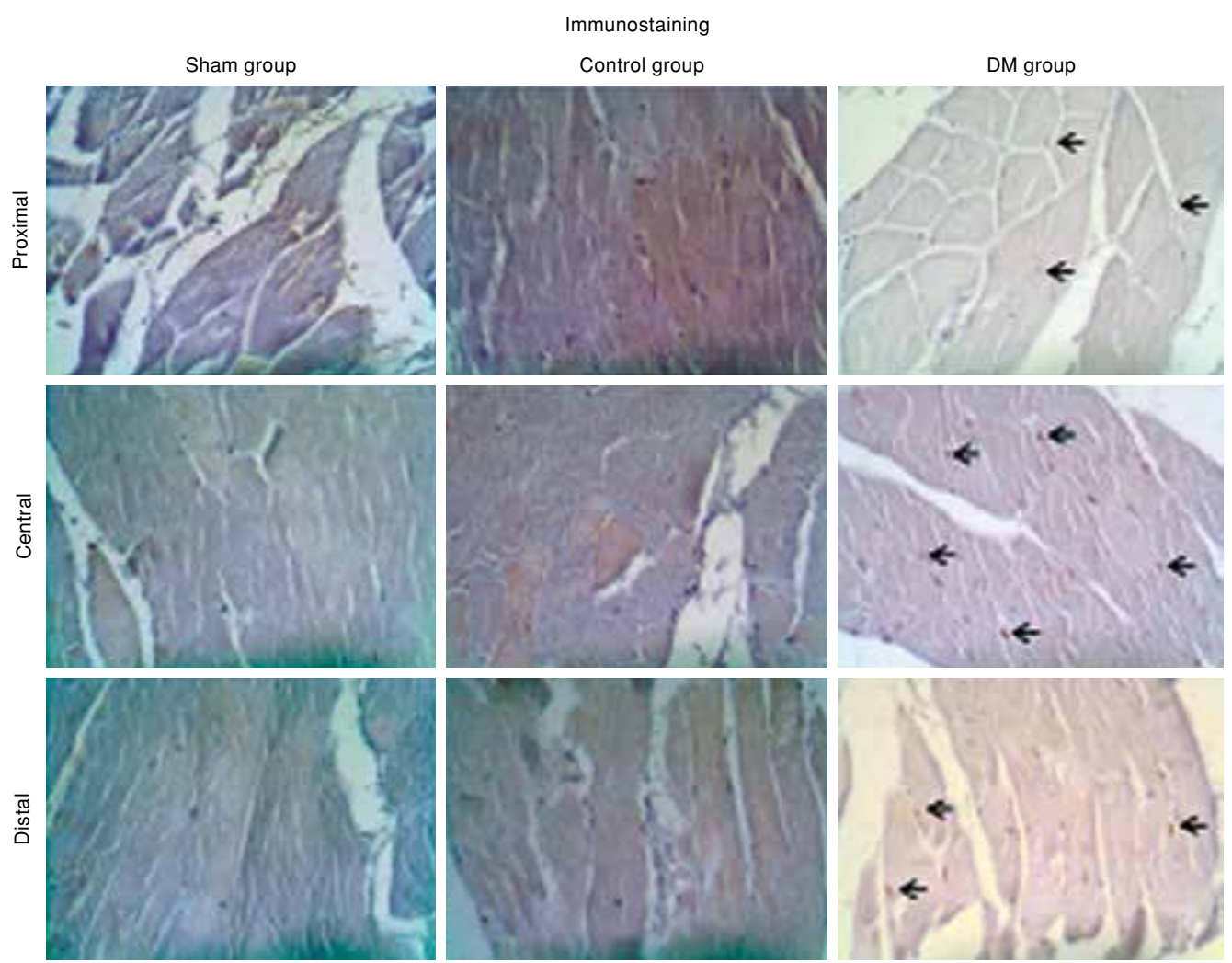

Figure 4. Photomicrograph of peroxisome proliferator-activated receptor gamma immunostaining. Peroxisome proliferator-activated receptor gamma positive cell count was significantly higher in diabetes mellitus group compared to other groups (black arrows). PPAR $\gamma$ : Peroxisome proliferator-activated receptor gamma; DM: Diabetes mellitus. 

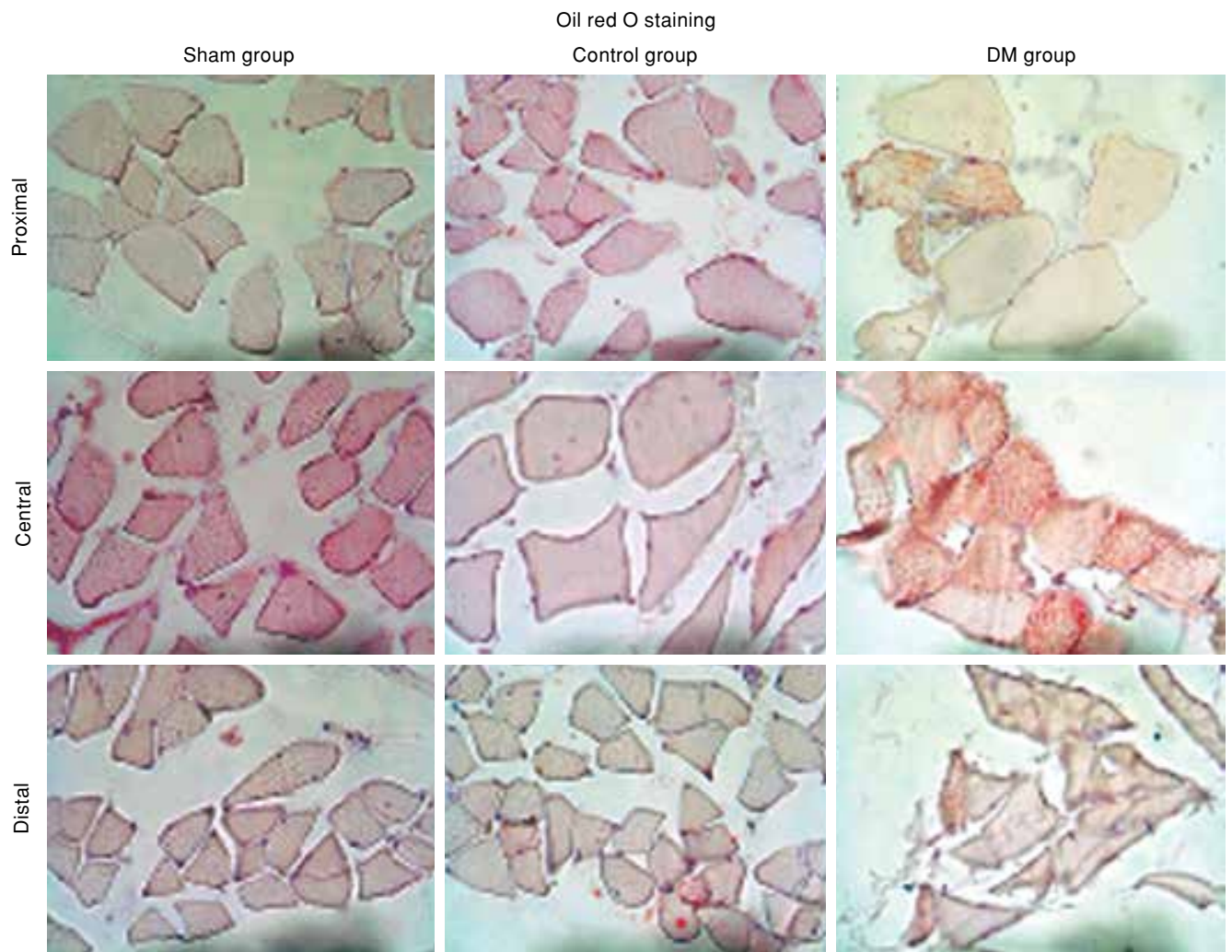

Figure 5. Photomicrograph of oil red $\mathrm{O}$ staining. Oil red $\mathrm{O}$ positive fat cell count was significantly higher in diabetes mellitus group compared to other groups.

this patient group, because fatty degeneration has a negative effect on the repair and is irreversible. . $^{[7,9]}$

Degenerative RC tears can be treated both conservatively and surgically. There is no exact determinative criterion when making this selection. According to the results of several studies comparing conservative versus surgical treatment of degenerative $\mathrm{RC}$ tear, similar functional results were reported up to three-year follow-up. ${ }^{[3,11]}$ However, DM was an exclusion criterion in these studies. Therefore, it is still not known whether this management strategy is valid for diabetic patients.
Several factors may play role on the healing of $\mathrm{RC}$ tears and the final clinical outcome. Some of these factors are not under the control of the surgeon, such as DM, the size of the RC tear, bone mineral density, amount of fatty degeneration and atrophy in RC muscles. ${ }^{[15,16]}$ Diabetes mellitus has been shown to be an important factor that affects both healing of the repaired tendon and functional results in experimental and clinical studies. Bedi et al. ${ }^{[10]}$ found significantly reduced collagen formation and fibrocartilage formation in diabetic rats compared to non-diabetic rats. These differences were accompanied

TABLE II

Summary of oil red $\mathrm{O}$ staining

\begin{tabular}{|c|c|c|c|c|c|c|c|c|}
\hline \multirow{2}{*}{$\begin{array}{l}\text { Oil red O } \\
\text { staining }\end{array}$} & \multicolumn{2}{|c|}{ Sham group } & \multicolumn{2}{|c|}{ Control group } & \multicolumn{2}{|c|}{ DM group } & \multirow[b]{2}{*}{ Significance } & \multirow[b]{2}{*}{$p$ value } \\
\hline & Mean $\pm S D$ & Range & Mean $\pm S D$ & Range & Mean \pm SD & Range & & \\
\hline Proximal & $113.7 \pm 10.3$ & $100-125$ & $115.0 \pm 15.8$ & $100-135$ & $227 \pm 42.8$ & $165-285$ & 0.001 & $0.899^{*}$ \\
\hline Central & $115.0 \pm 20.4$ & $100-145$ & $113.7 \pm 9.4$ & $100-120$ & $251.8 \pm 53.1$ & $130-300$ & 0.001 & $0.915^{\star}$ \\
\hline Distal & $120.0 \pm 12.9$ & $105-135$ & $126.2 \pm 16.5$ & $110-145$ & $230.0 \pm 43.0$ & $180-285$ & 0.001 & $0.573^{*}$ \\
\hline
\end{tabular}

DM: Diabetes mellitus; SD: Standard deviation; The second column $\left(^{*}\right) \mathrm{p}$ values show the comparison of the sham and control groups. 
by a corresponding reduction in the ultimate strength and stiffness of the repair construct. ${ }^{[10]}$ Furthermore, although there was improved functional outcomes and decreased pain scores in the diabetic population in clinical studies that compared the results of surgical treatment of RC tear among diabetic and non-diabetic groups, the results were reported to be worse than in the non-diabetic groups. ${ }^{[17]} \mathrm{Cho}$ et al. ${ }^{[18]}$ found that the outcomes of diabetic patients with good glycemic control were better than those of patients with poor glycemic control. These findings might be due to the adjuvant effect of DM on fatty degeneration.

The natural course of RC tears has been studied in non-diabetic patients, but it is not known how diabetes affects the natural course of RC tears. There has been little research on this subject. Thomas et al. ${ }^{[19]}$ compared shoulder joint mechanics, tendon properties (mechanics and immunohistochemistry), and the capsule of healthy control and hyperglycemic rats and demonstrated that DM induces a chronic inflammatory response. The recognition of the effects of DM at the molecular level on RC tears may be important in respect of the clinical manifestations.

In the current study, it was demonstrated that DM accelerates the progression of fatty degeneration after $\mathrm{RC}$ tears. According to these findings, caution should be taken when choosing conservative treatment for diabetic patients with RC tear; even early surgical treatment may be more beneficial. If conservative treatment is chosen, it may be useful to followup fatty degeneration closely while providing good glycemic control.

This study had several limitations. STZ is one of the most commonly used drugs to form an experimental diabetes model. ${ }^{[20]}$ Streptozotocin directly destroys pancreatic islet cells. Thus this model creates diabetes that is more similar to type 1 diabetes than insulin-resistant type 2 diabetes in humans. Although the development of each form of diabetes (type 1 or type 2) drastically differs, resultant pathologies and detrimental effects often overlap. Secondly, we waited four weeks after the induction of hyperglycemia to observe the chronic complications of DM on the muscle tissue. This period of time may be short; however, even four weeks of hyperglycemia induced significant detrimental effects in respect of fatty degeneration in the current study.

In conclusion, our study revealed that fatty degeneration was accelerated in diabetic rats compared to euglycemic group. The most important clinical implication of this study is on the selection of patients for conservative treatment or surgical repair in terms of timing. As fatty degeneration develops more rapidly in diabetics, it may be logical to follow-up these patients more closely and favor early surgical repair for these patients as fatty degeneration may adversely affect the outcome of treatments. Future treatment algorithms should include $\mathrm{DM}$ as a risk factor for fatty degeneration, while understanding the mechanisms behind this association may allow allocation of patients to appropriate treatment options.

\section{Declaration of conflicting interests}

The authors declared no conflicts of interest with respect to the authorship and/or publication of this article.

\section{Funding}

The authors received no financial support for the research and/or authorship of this article.

\section{REFERENCES}

1. Hsu JE, Gee AO, Lippitt SB, Matsen III FA. The rotator cuff. In: Rockwood Jr CA, Matsen III FA, Wirth MA, Lippitt SB, Fehringer EW, Sperling JW, editors. Rockwood and Matsen's the Shoulder. Philadelphia: Elsevier; 2017. p. 680-4.

2. Ağırman M, Leblebicier MA, Durmuş $O$, Saral İ, Gündüz $\mathrm{OH}$. Should we continue to administer blind shoulder injections? Eklem Hastalik Cerrahisi 2016;27:29-33.

3. Kukkonen J, Joukainen A, Lehtinen J, Mattila KT, Tuominen EK, Kauko T, et al. Treatment of Nontraumatic Rotator Cuff Tears: A Randomized Controlled Trial with Two Years of Clinical and Imaging Follow-up. J Bone Joint Surg [Am] 2015;97:1729-37.

4. Moosmayer S, Lund G, Seljom US, Haldorsen B, Svege IC, Hennig $\mathrm{T}$, et al. Tendon repair compared with physiotherapy in the treatment of rotator cuff tears: a randomized controlled study in 103 cases with a five-year follow-up. J Bone Joint Surg [Am] 2014;96:1504-14.

5. Başar S, Kanatlı U, Citaker S, Bölükbaşı S. Does presence of anterior greater tuberosity cysts change the function in patients with chronic rotator cuff tear? Eklem Hastalik Cerrahisi 2014;25:141-7.

6. Çift H, Özkan FÜ, Tolu S, Şeker A, Mahiroğulları M. Comparison of subacromial tenoxicam and steroid injections in the treatment of impingement syndrome. Eklem Hastalik Cerrahisi 2015;26:16-20.

7. Deniz G, Kose O, Tugay A, Guler F, Turan A. Fatty degeneration and atrophy of the rotator cuff muscles after arthroscopic repair: does it improve, halt or deteriorate? Arch Orthop Trauma Surg 2014;134:985-90.

8. Melis B, Nemoz C, Walch G. Muscle fatty infiltration in rotator cuff tears: descriptive analysis of 1688 cases. Orthop Traumatol Surg Res 2009;95:319-24.

9. Melis B, DeFranco MJ, Chuinard C, Walch G. Natural history of fatty infiltration and atrophy of the supraspinatus muscle in rotator cuff tears. Clin Orthop Relat Res 2010;468:1498-505.

10. Bedi A, Fox AJ, Harris PE, Deng XH, Ying L, Warren RF, et al. Diabetes mellitus impairs tendon-bone healing after rotator cuff repair. J Shoulder Elbow Surg 2010;19:978-88. 
11. Wolf BR, Dunn WR, Wright RW. Indications for repair of full-thickness rotator cuff tears. Am J Sports Med 2007;35:1007-16.

12. Wu KK, Huan Y. Streptozotocin-induced diabetic models in mice and rats. Curr Protoc Pharmacol 2008;5:47.

13. Liu X, Manzano G, Kim HT, Feeley BT. A rat model of massive rotator cuff tears. J Orthop Res 2011;29:588-95.

14. Tyagi S, Gupta P, Saini AS, Kaushal C, Sharma S. The peroxisome proliferator-activated receptor: A family of nuclear receptors role in various diseases. J Adv Pharm Technol Res 2011;2:236-40.

15. Chung SW, Oh JH, Gong HS, Kim JY, Kim SH. Factors affecting rotator cuff healing after arthroscopic repair: osteoporosis as one of the independent risk factors. Am J Sports Med 2011;39:2099-107.

16. Mall NA, Tanaka MJ, Choi LS, Paletta GA Jr. Factors affecting rotator cuff healing. J Bone Joint Surg [Am] 2014;96:778-88.

17. Clement ND, Hallett A, MacDonald D, Howie C, McBirnie J. Does diabetes affect outcome after arthroscopic repair of the rotator cuff? J Bone Joint Surg [Br] 2010;92:1112-7.

18. Cho NS, Moon SC, Jeon JW, Rhee YG. The influence of diabetes mellitus on clinical and structural outcomes after arthroscopic rotator cuff repair. Am J Sports Med 2015;43:991-7.

19. Thomas SJ, Sarver JJ, Yannascoli SM, Tucker JJ, Kelly JD 4th, Ahima RS, et al. Effect of isolated hyperglycemia on native mechanical and biologic shoulder joint properties in a rat model. J Orthop Res 2014;32:1464-70.

20. Al-Awar A, Kupai K, Veszelka M, Szúcs G, Attieh $Z$, Murlasits $Z$, et al. Experimental Diabetes Mellitus in Different Animal Models. J Diabetes Res 2016;2016:9051426. 